\title{
Science Processes Skills Acquisition \& Relationship thereof with Academic Level \& Students' Attitude towards the Laboratory
}

Dr. Mohammed S. Al-Rsa'I, Khetam M. Al-Helalat \& Reem Suleiman “Ali Saleh”

Al-Hussien Bin Talal University, Ma'an - Jordan

E-mail: rsaaie@ahu.edu.jo

Received: June 23, 2017 Accepted: July 20, 2017 Published: August 1, 2017

doi:10.5296/jse.v7i3.11562 URL: https://doi.org/10.5296/jse.v7i3.11562

\begin{abstract}
This study aimed to identify the acquisition degree of life sciences' students of science processes' skills and the relationship thereof with their academic level and attitude towards the laboratory. A test was designed to measure the science process skills while another was designed to measure lab interest. The generated outcomes showed weak degree average of such an attitude acquisition, though slight improvement with statistical significance, and academic level rise was noticed; (academic year). The study also, showed high and stabled attitude of life sciences section students in Al-Hussein Bin Talal University towards labs during study years. There was no liaison between the possessing degree of science processes and their attitude toward the lab. Therefore we recommended herein the need arise herein to invest the students wish in lab works in order to raise their science process skills and to develop teaching strategies used in teaching within the lab premises.
\end{abstract}

Keywords: Science Processes, Attitude Towards the Lab, Life Sciences, Academic Level. 


\section{Introduction}

Science is classified as a dynamic interaction between processes and outcomes rather than being a description of the natural phenomena. Science Process skills include life learning skills used by the learner to deal with the daily life problems (Zaytoon, 2002).

That is why the learning process is not limited to providing the learner with only scientific knowledge, but the most important is to convert the knowledge into behavior, through which the learner can solve problems in a creative scientific method that helps him to keep on with the scientific, technological progress, and the human knowledge development, (Al Dosari, 2013, Ata Allah 2001), and to face the $21^{\text {st }}$. century current and future requirements and challenges.

Therefore, science process tests become a necessity to measure the science importance extent as to intellectual aspect of the learner, and further is to measure its impact through being aware of the acquired skills; starting from observation and measurement, classification and prediction skills, reasoning and communication, data interpretation, procedural definitions, variables adjustment, hypothesis formulation accessing to trial skills; (Partick, 2010; Baxter \& Kurtz, 2001).

Science processes are considered as a group of mental special capacities and processes which are necessary for applying learning methods and scientific thinking in accurate manner (Zaytoon 2010). Therefore, it is considered a basis of scientific exploration and discovery (Khatabiah, 2008; Sen\& Vekli, 2016). They to develop ability for self teaching, critical and creative thinking (Olayan 2010; Lord \& Orkwiszewski, 2006); furthermore, they help for self-access to information, educational process core, carrying learning impact towards new stands, offering positive attitude for science processes towards environment and maintaining it, and these are increase their various scientific attitudes (Zaytoon, 2010; Al Swaidi, 2010; Abu Athrah, 2012).

The foregoing recognize the learning process importance in the educational process and its positive role to construct knowledge, maintaining it and linking it with the learners to solve their life problems.

Science processes are indentified to be "a group of human's basic mental processes, which include a number of necessary mental skills for solving problems in a sound and logical manner. Such processes help man to organize comments, collect data, delimit efforts and to direct it in appropriate manner towards the problem" (Abu Athrah, 2012, p81).

On the other hand, Gagne affirms that science processes are the core of scientific discovery and exploration and furthermore these are marked by the fact that they are defined as limited mental skills used by scientists (individuals and learners) to understand the cosmic phenomena and existence. Besides, these are considered as limited behavior for scientists, which could be acquired, rehearsed, circulated, and practiced in our life. Many daily life problems may be studied, analyzed, and set out suitable solutions thereto, once applying science processes skills. ( Zaytoon, 2008) 
Within this scope, we may assure the learning motivation and self-growth of the educated student. Such a student should keep inquiring, thinking, searching, discovering and investigating instead of receiving information and memorizing it once needed. Nevertheless, it is more important to study Inquiry science as subject and practical scientific method (Zaytoon, 2008), which has been assured by the National standards of the scientific education in USA. Those standards include four principles or sub-standards to teach science; i.e. science for all students, science learning is an active process focusing on search, discovery and achieving high levels of scientific culture, better understanding thereof, developing sciences teaching as part of the general educational development which involve all who are engaged in Scientific teaching; i.e. teachers, students and programs. (NSES, 1996).

Olayan $(2010$, p64) states that science processes are certain mental processes practiced, mostly, in labs to generate outcomes, verifying them and to determine as well. From this point, Lab role is apparent in terms of offering the students such skills, compared with learning in the traditional class room (Tsai, 2003). This leads us to say that educated students acquisition of the basic and integrated science processes is the most important objective to conduct studies in the Lab. On the other hand, life sciences lab is marked by the activities variety that suits to develop all science skills and processes. Most of such practical activities in the lab are based on observation and classification of the samples and micro slices, in addition to testing. Also it includes other skills; i.e. measurement, collecting information, predicting, variables adjustment and definition, using figures, expressing via drawing, words or shapes which shall, indeed, develop communications skills as one of science processes which are witnessed clearly in the educated person's life'. The studies showed that the opportunity to offer science process skills of life science students in the competent lab requires using educational strategies to prepare and enhance such an opportunity, high motivation to work in the lab, positive attitudes and scientific experiments. (Howard \& Miskowski, 2005).

The academic plans in the life sciences departments offer wide range for scientific subjects due to what such a subject content imposes (wood 2003). The foregoing contributes in deepening the students' skills inside the lab; i.e. science skills and repetitions which make students' capabilities and scientific skills increase.

Science process skills which may be developed in the life sciences lab are variable, and thus they are distributed to skills and basic processes occupying the process learning pyramid base. (Zaytoon, 2010). It is also defined by (Carin \& Sund, 1975) as those processes which offer main understanding to the learner to assimilate and master the scientific subject, which is less complicated than integral science processes which are featured by complexity and thus occupying the science process pyramid summit.

Therefore science process skills are divided into two parts (Martin, Sexton \& Geriovich, 2001; Naiwashi, 2007, AmbuSaidi\&Bloshi, 2011). 


\section{Literature Review}

\section{Science Process Skills}

\section{Basic Science Process Skills}

Those include observation skills, which are considered the basic process whereas the learner uses his senses to have access to information. The life sciences' learner uses his vision to study micro slices, distinguish colors, sizes and else. But, he is not allowed to use smell sense or taste sense in the lab as it is dangerous. The learner should acquire accurate observation in terms of quality and quantity, considering differences among similar things. Moreover, measuring skill shall be mastered as well which describes the spatial relationships by using various tools such as microscopes, lens, scales and many other devices, which the learner should learn using them skillfully, And using mathematical calculations as well. Classifying skills depend on classifying things into groups pursuant to certain characteristics. On the other hand, biology scientists divide organisms into plants and animals which the learner uses in life sciences scope to identify similarity and difference between cells or animals for example.

Out of basic science processes skills what is called Inferring, which is mental process which interprets and clarifies observations on phenomena connected to organisms and bioprocess. The foregoing, mostly, depends on previous expertise through which the conclusion is derived from the observations. Such observations must be in consistent with the conclusion or reject it. Besides, Predicting skill which is represented by phenomena prediction to take place in time to be based on observations or realities is a prediction which is established on realities subject to observation, and further thorough understanding of cause and effect relationship.

The learner ability to communicate his ideas, information or its scientific outcomes to others is referred to by communication skills. Such communication is made through translating such ideas, principles and information into tables; either verbally or in writing, via charts, setting out schedules and writing reports. The foregoing could be achieved by accurate scientific expression, good listening and discussing with others and scientific critic reading, which life sciences students shall master. When the learner uses numbers to express an idea, notice or relationship, then using numbers skill is developed and such is referred to as math skill. Using space-time relationship is the last basic skill that works to promote spatial relationships description skills and changes thereof over time, which includes studying the ambiguity, similarity and movement that aim to provide the learner with ability to draw 3D drawings.

\section{Integrated Science Process Skills}

These skills occupy the scientific process summit. Integration feature thereof is selected as it works to merge many basic skills to solve the problem in an efficient mode. Such skills are not acquired by the learner, unless he masters the basic skills. Such skills include Data Interpretation represented by the relationship understanding between the content parts, recognize, re-organize and connect them with the learner's previous expertise. Interpretation includes the learner's ability to summarize the ideas of the situation and assess the content factors. 
As far as procedural definitions are concerned, this is a process used to describe things, events or phenomena. It depends on the learner's observation, performance and expertise. While controlling variables skill is the ability to isolate the variables which could be casual, and to confirm other factors in order to define the causal function of single factor. This process opens the way to discover the relationship among cause, outcome and effect. Therefore, the learner at the university must recognize the variables that lay its influence in certain stand, which are classified as follows:

Independent variables, dependent variables, fixed variables and uncontrolled variables.

Out of science integrated skills is Formulating Hypotheses skill, which is a design established on a group of observations or conclusions. Such a hypothesis needs to be tested. Such a test is scheduled under circulations including a group of observations enriched by other observations, and then the hypothesis is amended or rejected upon collecting information which supports such hypothesis. Such hypothesis aims to interpret a phenomenon which is subject to research and further open the way before new observations and conclusions.

Finally, experimenting skill occupies the summit position in science processes. Experiments open the way for new discoveries in terms of concepts and principles which need more assurance, and further, it generates new experiments, which is the most important in the scientific search operations.

Many studies tackled such a subject and referred to the weak level of the students in science colleges in terms of science processes (Khatabiah \& Baarah 2002; Zaytoon, 2008; Suarez, 2011). Such weakness is attributed to many reasons; i.e. the students' attitudes towards lab function, enjoyment degree to perform experiments and scientific survey (Laipply, 2004). Nevertheless, the students' academic level, their academic knowledge and skills development at their University studies contribute, for sure, to equip them with science processes, especially if they are subject to theoretical and practical subjects which work to equip the students from gaining such skills in addition to scientific knowledge. (Myers \& Burgess, 2003; Brownell, Kloser, Fukmi \& Shavelson, 2012).

Therefore, this study aimed at identifying firstly the acquirement degree of science processes among students who are enrolled in life sciences section at Al- Hussien Bin Talal University, and whether this degree differ by academic level thereof. Secondly it drives at identifying the relationship between respective students' possessing level of scientific processes and their lab visits.

\section{Method \& Procedures}

\section{Population and Sample}

The study Population consists of 186 students from life sciences section in Al- Hussien Bin Talal University at the four academic years (First, Second, Third \& Forth) for the academic year 2014/2015, totaled at (186) Students. 


\section{Macrothink}

On the other hand, the research sample was selected from all academic years (males and females) which was an intentional sample, totaled at 132 students. Such a sample was rated at $71 \%$ of the community sample.

Table 1 shows the research sample individuals distribution based on academic years as follows:

Table 1. Research Sample Individuals according to Academic Years

\begin{tabular}{|l|c|}
\hline $\begin{array}{l}\text { Academic } \\
\text { Year }\end{array}$ & $\begin{array}{c}\text { Number of } \\
\text { Students }\end{array}$ \\
\hline First & 48 \\
\hline Second & 26 \\
\hline Third & 25 \\
\hline Forth & 33 \\
\hline Total & 132 \\
\hline
\end{tabular}

\section{Study Tool}

The research tool was designed to be a test of scientific process skills. Such a test was an objective test (multiple choice test) variable, which covers all science process skills. The student selects the answer out of four alternatives to decrease guessing and increase the test credibility.

The research tool has been presented to (7) competent arbitrators who teach science and science teaching methods, and a number of the teaching body at the same university ( life sciences section) to set out their opinion on the test paragraph suitability \& inclusiveness to measure science processes. Also we defined the difficulty and preference coefficients of the test paragraphs through initial experiments on initial sample rather than research sample. All the paragraphs were suitable.

In order to identify the test stability, we re-applied the test on initial sample after 42 days elapse, and the test stability coefficient at $(0.82)$ which is a suitable value herein.

\section{Result}

\section{Science Process Skills}

In order to identify acquisition degree of life sciences students at Al- Hussien Bin Talal University in terms of science process, we have calculated the SMAs and standard deviations of their degrees on science process test which was prepared for such an issue. Table No. (2) Sets out students outcomes on such a test. 


\section{Macrothink}

Table 2. SMAs \& standard deviations in terms of students acquisition of science processes

\begin{tabular}{|l|c|c|c|}
\hline $\begin{array}{l}\text { Academic } \\
\text { Level }\end{array}$ & Number & SMA & $\begin{array}{c}\text { Standard } \\
\text { Deviation }\end{array}$ \\
\hline First & 48 & 5.31 & 2.37 \\
\hline Second & 26 & 5.38 & 1.98 \\
\hline Third & 25 & 5.76 & 2.06 \\
\hline Forth & 33 & 6.75 & 2.33 \\
\hline Total & 132 & 5.77 & 2.33 \\
\hline
\end{tabular}

Table 2 displays that the students acquisition degree of science processes was low in all academic levels. The students performance level in all academic years on science processes test was (5.77), at standard deviation of 2.33. Noting that the total mark of the test was (13). Figure 1 clarifies such SMAs for each year.

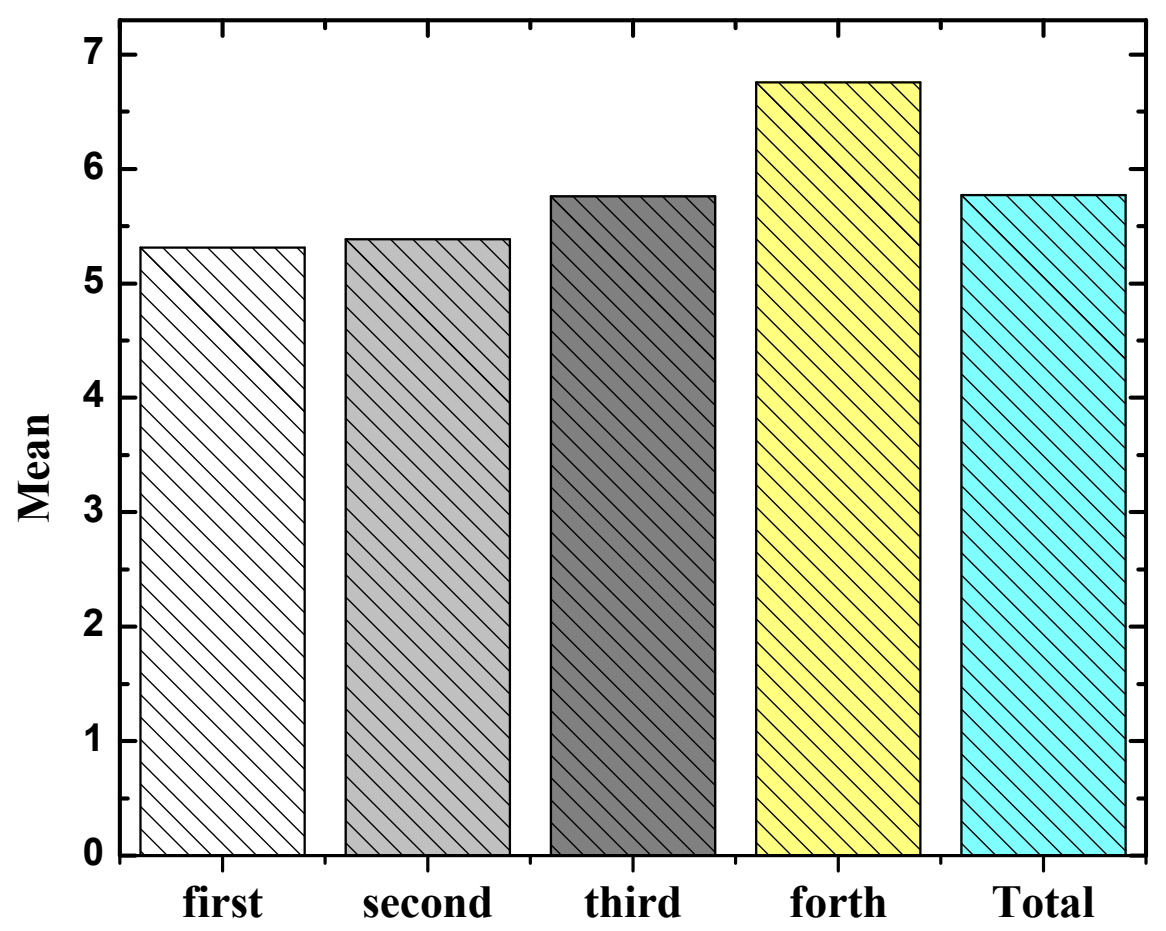

Figure 1. SMAs in terms of students acquisition of science processes

In order to identify the differences coefficient between students SMAs by their academic level differences, we used One-way Anova analysis, outcomes of which are presented in Table (3) hereinafter. 
Table 3. One-way Anova analysis between students SMAs

\begin{tabular}{|l|c|c|c|c|c|}
\hline & $\begin{array}{c}\text { Sum of } \\
\text { Squares }\end{array}$ & Df & $\begin{array}{c}\text { Mean } \\
\text { Square }\end{array}$ & F & Sig. \\
\hline Between Groups & 43.48 & 3 & 14.49 & & \\
\cline { 1 - 4 } Within Groups & 625.395 & 128 & 4.88 & \multirow{2}{*}{4.939} & \multirow{2}{*}{.035} \\
\cline { 1 - 3 } Total & 668.879 & 131 & & & \\
\hline
\end{tabular}

Table 3 refers to the differences between SMAs of life sciences students' acquisition as to sciences processes of statistical significance. In order to identify the group which such differences are in its favor, we have conducted comparisons between such SMAs via Shefa's test as displayed in table 4.

Table 4. Shefa's test for comparisons between such SMAs

\begin{tabular}{|lc|c|c|}
\hline (I)Study Year & $\begin{array}{c}\text { (J)Study Year } \\
\text { Fean Difference } \\
\text { (I-J) }\end{array}$ & Sig. \\
\hline Thirst & Second & -0.225 & 0.981 \\
Forth & & -0.447 & 0.879 \\
\hline Second & & $-1.219^{*}$ & 0.043 \\
Forth & Third & -0.221 & 0.346 \\
\hline Third & & $-2.142^{*}$ & 0.005 \\
\hline
\end{tabular}

The subsequent comparisons, referred to in Shefa's test analysis, show that the differences between SMAs in the acquisition degree of the respective students as to the science processes was of statistical significance among the first academic year students, the forth academic year students from one side and the second academic year students, the forth Academic year students from the other side. Also there were no material differences between the $3^{\text {rd }}$. academic year students and other academic years' students.

As far as auxiliary skills are concerned, Table 5 displays basic science processes SMAs of the life sciences students. 
Table 5. Basic science processes SMAs of life sciences students

\begin{tabular}{|c|c|c|}
\hline $\begin{array}{c}\text { science } \\
\text { processes skills }\end{array}$ & Mean & $\begin{array}{c}\text { Std. } \\
\text { Deviation }\end{array}$ \\
\hline Observation & 0.310 & 0.464 \\
\hline Measurement & 0.295 & 0.457 \\
\hline Classification & 0.439 & 0.498 \\
\hline Inferring & 0.295 & 0.457 \\
\hline Prediction & 0.530 & 0.500 \\
\hline Communication & 0.409 & 0.493 \\
\hline Using Numbers & 0.515 & 0.501 \\
\hline Space - Time & 0.507 & 0.501 \\
Relationships & & \\
\hline
\end{tabular}

The values of SMAs show that (Prediction, Using Numbers and Space - Time Relationships) have the highest value for the basic science skills in laboratory. Figure 2. This may happen because these skills are most commonly used in the laboratory

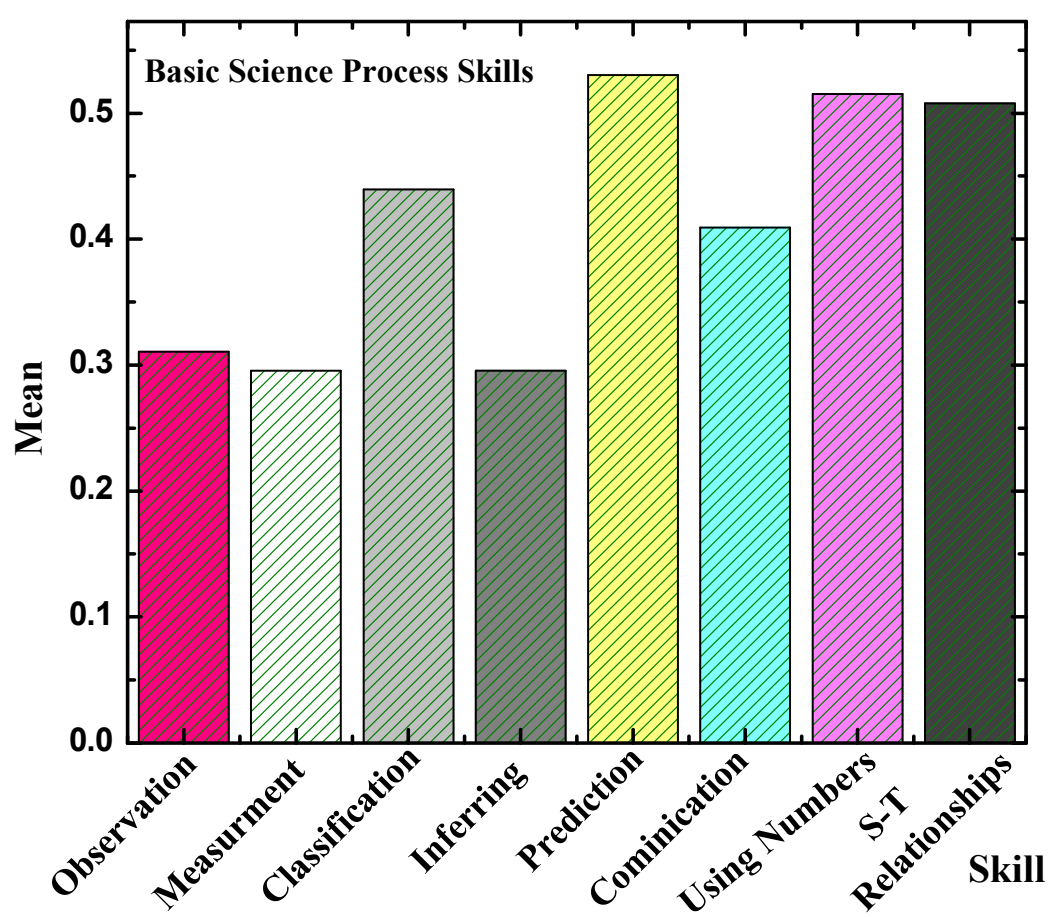

Figure 2. Basic science processes SMAs of life sciences students

The Integrated science processes SMAs of the life sciences students acquisition are shown in Table 6. 


\section{Macrothink}

Table 6. Integrated science processes SMAs of life sciences students

\begin{tabular}{|l|c|c|}
\hline & Mean & Std. Deviation \\
\hline Interpreting Data & 0.424 & 0.496 \\
\hline Defining Operationally & 0.500 & 0.501 \\
\hline Controlling Variables & 0.348 & 0.478 \\
\hline Formulating Hypotheses & 0.575 & 0.496 \\
\hline Experimentation & 0.598 & 0.4920 \\
\hline
\end{tabular}

The differences between the Integrated science processes SMAs were modest. Figure(3), The reason may be due to the nature of teaching in the laboratory, where the students are deprived of the practice and training of all these skills.

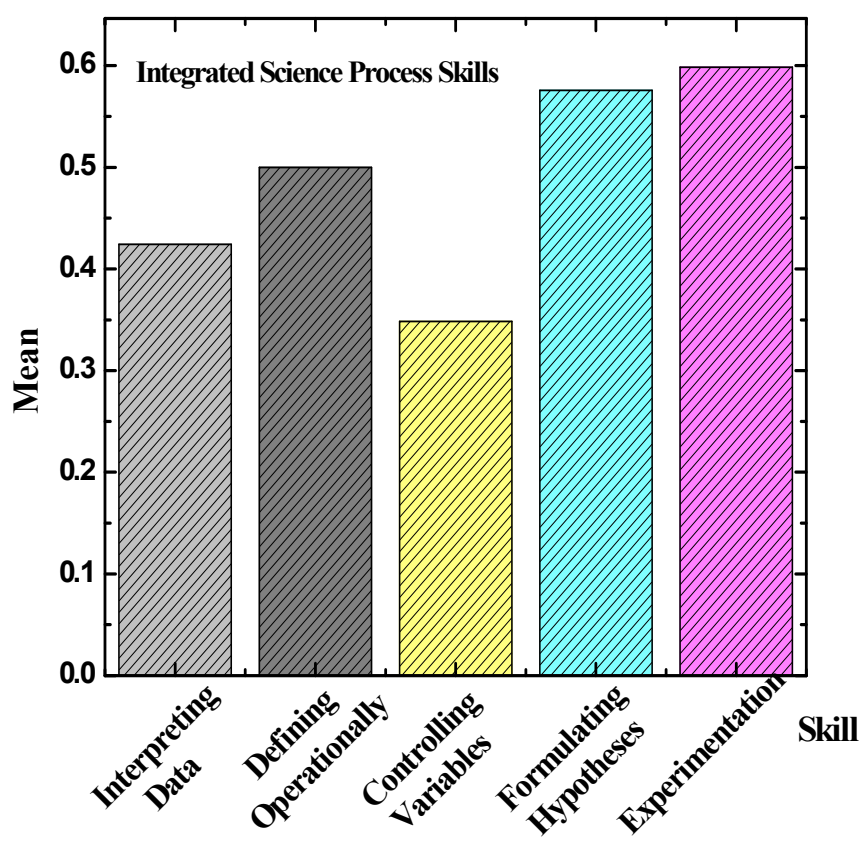

Figure 3. Integrated science processes SMAs of life sciences students

\section{Visiting the Labs}

In respect of the life sciences students, we have extracted the students' replies on the attitude scale prepared for such issue at the same university. Table (7) shows SMAs and standard deviations of the sample individuals' attitude towards lab visits. The respondents to the scale were (130). 
Table 7. SMAs \& Standard Deviations of the Sample Attitude Towards Lab

\begin{tabular}{|l|c|c|c|}
\hline Academic & Number & SMA & Standard \\
\hline First & 48 & 80.12 & 13.95 \\
\hline Second & 25 & 76.70 & 13.66 \\
\hline Third & 24 & 71.89 & 19.26 \\
\hline Forth & 33 & 75.01 & 15.69 \\
\hline Total & 130 & 76.65 & 15.56 \\
\hline
\end{tabular}

Table 7 displays the SMAs of the students attitude towards the lab, and the SMAs was high level. In order to identify differences significance between SMAs, we used One way Anova, results of which in Table No. (8).

Table 8. One way Anova analysis for SMAs Attitude Towards Lab

\begin{tabular}{|c|c|c|c|c|c|}
\hline & Sum of & & Mean & & \\
\hline & Squares & Df & Square & $\mathbf{F}$ & Sig. \\
\hline Between Groups & 1212.909 & 3 & 404.303 & \multirow{3}{*}{1.696} & \multirow{3}{*}{.171} \\
\hline Within Groups & 30043.732 & 126 & 238.442 & & \\
\hline Total & 31256.641 & 129 & & & \\
\hline
\end{tabular}

Table 8 presents the absence of differences of statistical significance between the students of SMAs at the same university, with the difference in the academic year; i.e. their attitude towards lab function did not change by statistical significance during their academic promotion even though they practiced such levels lab visits and practical subjects. The positive attitude herein is that students' attitude towards the lab remained high during their academic years.

In order to specify the correlation of the students' possession of attitude towards lab function we have calculated Persons correlation coefficient between the SMAs of sample individuals attitude towards lab function and their performance SMA on the science process test as presented in Table 9. 
Table 9. Person correlation coefficient between sample attitude towards lab function and their performance SMA on science process test

\begin{tabular}{|l|c|c|}
\hline & $\begin{array}{c}\text { Correlation } \\
\text { Coefficient }\end{array}$ & $\begin{array}{c}\text { Significance } \\
\text { Level }\end{array}$ \\
\hline $\begin{array}{l}\text { Science Processes } \\
\text { Attitude toward Lab Work }\end{array}$ & 0.130 & 0.136 \\
\hline
\end{tabular}

Table 9 showed the absence of correlation between the students attitude towards Lab work and science process possessing level. This means that the availability of other effective factors in science process level of the students which they gain mostly from lab work, are connected to employ teaching strategies.

\section{Discussing the results}

The study outcomes showed that the acquisition degree of science process skills is weak, even though it witnessed slight improvement during their academic level promotion. This gives evidence to the teaching ability weakness during the University study years which laid its effects on the students' science process skills development. The cause behind such weakness is due to the traditional teaching strategies adopted at the university. (Kloser, Brownell, Chiariello, \& Fukami, 2011). Such traditional strategies are based on the major role of the university lecturer in the classroom whereas he uses the ready information without room for the students to searching and investigating the various thinking skills. On the other hand, teaching strategies are almost free from addressing questions and raising discussions inside the classroom.

The university mostly employs (cook book strategy) in the scientific subject practical evidences. The foregoing strategy requires the student to carry out experimental procedures, objective steps and which are neither understood nor outreached (Handelsman. Et.al2004, Brownell, Kloser, Fukami, \& Shavelson 2012). This is why this study sets out recommendations to re-design work guidelines in labs, in order to be in line with modern strategies used in University teaching, especially teaching in the labs. Moreover, the students have to be delegated to research missions to reply the major questions raised in the labs; or what is called (Free Investigation), and further offer them main roles and wide responsibility inside the lab. Other recommendations are focused on the participation of specialized individuals in designing sciences methodologies in preparing the lab outcomes to include scientific research skills and science processes.

It is interesting to consider the outcomes of this study, what relates to students attitude in Hussain Ben Talal University toward lab work practice which registered positive and high results; i.e. the students go to work in the lab full of motivation and wish, but this was not reflected on their science processes acquisition and research skills as well. In that regard, those who are entrusted of teaching in life sciences sections lose such an opportunity to invest such wish to increase the students' attainment and acquiring basic skills of science processes. The positive impact efficiency of the students' motivation and attitude towards the lab is assured on their knowledge attainment and targeted skills (Weinburgh \& Englehard, 1994, Howard \& 
Miskowski, 2005). Students' attitudes towards science grow mostly if teaching in the lab is existed in a way to link what students learn from their reality and life, and to make opportunity available for them to design the lab work and discover scientific principles (Mathews, Adams \& Goos, 2010).

\section{References}

Abu Athrah, S. (2012).Develop Science Concepts \& Science Process Skills. Amman:Society Dar.

Al Dosari, N. (2013). The level of mastery of students in the sixth grade of primary science operations. Unpublished Master Thesis, King Saud University, Saudi Arabia.

Al Swaidi,B. (2010). The level of proficiency of students in the ninth grade of basic education for basic science operations in science. Damascus University Journal, 26.

AmbuSaidi, A., \& Bloshi, S. (2011). Science Teaching Methods. Second Edition. Amman: Almaseera Dar.

Ata Allah, M. (2001). Methods of teaching science. $1^{\text {St }}$ Edition. Amman: Almaseera Dar.

Baxter, L. M., \& Kurtz, M. J. (2001). When a Hypothesis is NOT an Educated Guess. Science \& Children, 38(7), 18-20.

Brownell, S. E., Kloser, M. J., Fukami T., \& Shavelson, R. (2012). Undergraduate biology lab courses: Comparing the impact of traditionally based "cookbook" and authentic research-based courses on student lab experiences. Journal of College Science Teaching, 41(4), 36-45.

Carin, A. A., \& Sund, R. B. (1975).Teaching modern science. Columbus, Ohio: C E Merrill, 1975 ISBN: 067586949.

Handelsman J., Ebert-May, D., Beichner, R., Bruns, P., Chang, A., Dehaan, R., Gentile, J., Lauffer, S., Stewart, J., Tilghman, S. M., \& Wood, W. B. (2004).Scientific teaching. Science, 304, 521-522. https://doi.org/10.1126/science.1096022

Khatabiah, A., \& Baarah, H. (2002). Chemical Student's Understanding of Basic \& Integrated Science Process Skills. Arab Union Journal of Education \& psychology, 2(1).

Khatabiah, A. (2008). Teaching Science for all. Second Edition.-Amman:Dar Almaseera.

Howard, D. R., \& Miskowski, J. A. (2005). Using a module-based laboratory to incorporate inquiry into a large cell biology course. Cell Biology Education, 4, 249-260. https://doi.org/10.1187/cbe.04-09-0052

Kloser, M. J., Brownell, S. E., Chiariello, N. R., \& Fukami, T.(2011). Integrating teaching and research in undergraduate biology laboratory education. PloS Biology, 9(11), 1-3. https://doi.org/10.1371/journal.pbio.1001174

Laipply, R. S. (2004). A case study of self-efficacy and attitudes toward science in an inquiry-based biology laboratory. PhD Thesis, Akron University. 
Lord, T., \& Orkwiszewski, T. (2006). Moving from didactic to inquiry-based instruction in a science laboratory. The American Biology Teacher, 68(9), 342-345. https://doi.org/10.1662/0002-7685(2006)68[342:DTIIIA]2.0.CO;2

Martin, R., Sexton, C., \& Gerlovich, J. (2001).Teaching Science for all children. 3rd. ed., Massachusetts, Allyn and Bacon, Inc, U.S.A

Mathews, K. E., Adams, P., \& Goos, M. (2010). Using the principles of BIO2010 to develop an introductory, interdisciplinary course for biology students. CBE-Life Science Education, 9, 290-297. https://doi.org/10.1187/cbe.10-03-0034

Myers, M. J., \& Burgess A. B. (2003). Inquiry-based laboratory course improves students' ability to design experiments and interpret data. Adv. Physiol. Educ, 27(1), 26-33. https://doi.org/10.1152/advan.00028.2002

Naiwashi, Q. (2007). Science for all children and their practical applications. $1^{\text {St }}$ Edition. Amman: Dar Almaseera.

NSES. (1996). National Science Education Standards. National Academy Press, Washington, Dc.

Olayan, S. (2010). Natural science curricula and methods of teaching. Theory and practice.Almaseera Dar. Amman.

Partick, O. A. (2010). Processes of science skills acquisition: competences required of science teacher for imparting them. Journal of Qualitative Education, 6(4), 1- 148. Japan.

ŞEN,C., \& VEKLİ, S. (2016). The Impact of Inquiry Based Instruction on Science Process Skills and Self-efficacy Perceptions of Pre-service Science Teachers at a University Level Biology aboratory. Universal Journal of Educational Research, 4(3), 603-612. https://doi.org/10.13189/ujer.2016.040319

Suarez, M. L. (2011). The relationship between inquiry-basedscience instruction and student achievement. Unpublished Doctoral Dissertation, The University of Southern Mississippi, Mississippi.

Tsai, C-C. (2003). Taiwanese science students' and teachers' perceptions of the laboratory learning environments: exploring epistemological gaps. International Journal of Science Education, 25(7), 847-860. https://doi.org/10.1080/09500690305031

Weinburgh, M.H. \&Englehard, G.Jr. (1994). Gender, prior academic performance and beliefs as predictors of attitudes towards biology laboratory experiences. School Science \& Mathematics, 94(3), 118-123. https://doi.org/10.1111/j.1949-8594.1994.tb15635.x

Wood, W. B. (2003). Inquiry-based undergraduate teaching in the life sciences at large research universities: A perspective on the Boyer Commission report. Cell Biology Education, 2, 112-116. https://doi.org/10.1187/cbe.03-02-0004 


\section{Macrothink}

Journal of Studies in Education

ISSN 2162-6952 2017, Vol. 7, No. 3

Zaytoon, A. (2008). The extent to which science processes are acquired by students in the basic stage in Jordan and its relation to the variables of the academic grade and achievement. Dirasat. Educational Science, 35(2), 327-397.

Zaytoon, A. (2010).Contemporary global trends in science curricula and teaching. Dar Alashoroug. Amman.

Zaytoon, K. (2002). Teaching science to understand. $1^{\text {St }}$ Edition.alam Alkotob- Cairo.

Zaytoon, K. (2009). Science Processes and scientific teaching. Alam Alkotob- Cairo. 